\begin{tabular}{|} 
Ambiente \& Água - An Interdisciplinary Journal of Applied Science \\
ISSN 1980-993X - doi:10.4136/1980-993X \\
www.ambi-agua.net \\
E-mail: ambi.agua@gmail.com
\end{tabular}

\title{
Impact of climate change on monthly streamflow in the Verde River Basin using two hydrological models
}

\author{
ARTICLES doi:10.4136/ambi-agua.2683
}

Received: 01 Dec. 2020; Accepted: 24 May 2021

\begin{abstract}
Vinícius Siqueira Oliveira Carvalho ${ }^{1 D}$; Lívia Alves Alvarenga ${ }^{2}$; Conceição de Maria Marques de Oliveira ${ }^{3 *}$; Javier Tomasella ${ }^{4}{ }^{\mathbb{D}}$; Alberto Colombo ${ }^{2}$; ; Pâmela Aparecida Melo ${ }^{2}$
\end{abstract}

\footnotetext{
${ }^{\mathbf{1}}$ Faculdade de Engenharia Civil, Arquitetura e Urbanismo. Universidade Estadual de Campinas (UNICAMP), Rua Saturnino de Brito, n²24, CEP: 13083-889, Campinas, São Paulo, Brazil. E-mail: vsiqueira18@gmail.com

${ }^{2}$ Departamento de Recursos Hídricos e Saneamento. Universidade Federal de Lavras (UFLA), Caixa Postal 3037, CEP: 37200-900, Lavras, MG, Brazil. E-mail: livia.aalvarenga@drs.ufla.br, acolombo@ufla.br,pam.melo.al@gmail.com

${ }^{3}$ Departamento de Engenharia Agrícola. Universidade Estadual do Maranhão (UEMA), Cidade Universitária Paulo VI, Caixa Postal 09, CEP: 65725-000, São Luís, MA, Brazil.

${ }^{4}$ Coordenação Geral de Pesquisa e Desenvolvimento. Centro Nacional de Monitoramento e Alertas de Desastres Naturais (CEMADEN), Rodovia Presidente Dutra, Km 40, SP-RJ, CEP: 12630-000, Cachoeira Paulista, SP, Brazil. E-mail: javier.tomasella@ cemaden.gov.br

*Corresponding author. E-mail: cita_mo@yahoo.com.br
}

\begin{abstract}
This study assessed the impact of climate change on monthly streamflow in the Verde River Basin, located in the Grande River Basin headwater. For this purpose, the SWAT and VIC hydrological models were used to simulate the monthly streamflow under RCP4.5 and RCP8.5 scenarios, obtained by Regional Climate Models Eta-HadGEM2-ES, Eta-CanESM2 and Eta-MIROC5 in the baseline period (1961-2005) and three time-slice (2011-2040, 20412070, and 2071-2099) inputs. At the end of the century, the Eta-HadGEM2-ES showed larger decrease of precipitation in both radiative scenarios, with an annual reduction of 17.4 (RCP4.5) and $32.3 \%$ (RCP8.5), while the Eta-CanESM2 indicated major warming, with an annual increase of 4.7 and $10.2^{\circ} \mathrm{C}$ under RCP4.5 and RCP8.5, respectively. As well as precipitation changes, the Eta-HadGEM2-ES also showed greater impacts on streamflow under RCP4.5 for the first time-slice (2011-2040), with an annual decrease of $58.0 \%$ for both hydrological models, and for the RCP8.5 scenario by the end the century (2071-2099), with an annual reduction of 54.0 (VIC model) and $56.8 \%$ (SWAT model). Regarding monthly streamflow, the Eta-HadGEM2-ES and Eta-CanESM2 inputs indicated decrease under the RCP8.5 scenario by the end the century, varying from 7.2 to $66.3 \%$ (VIC model) and 37.0 to $64.7 \%$ (SWAT model). In general, Eta-MIROC5 presented the opposite in terms of direction in the simulations with both hydrological models at the end of the century. Combined effects of climate models, hydrological model structures and scenarios of climate change should be considered in assessments of uncertainties of climate change impacts.
\end{abstract}

Keywords: climate change, Eta-CanESM2, Eta-HadGEM2-ES, Eta-MIROC5, SWAT model, VIC model. 


\section{Impactos das mudanças climáticas na vazão mensal da bacia do Rio Verde usando dois modelos hidrológicos}

\section{RESUMO}

O objetivo deste estudo foi avaliar os impactos das mudanças climáticas nas vazões mensais da bacia hidrográfica do rio Verde, localizada na bacia hidrográfica de cabeceira do rio Grande. Para este propósito, os modelos hidrológicos SWAT e VIC foram usados para simular a vazão mensal sob os cenários RCP4.5 e RCP8.5, obtidos pelos Modelos Climáticos Regionais Eta-HadGEM2-ES, Eta-CanESM2 e Eta-MIROC5 no clima presente (1961- 2005) e em três intervalos de clima (2011-2040, 2041-2070 e 2071-2099). No final do século, o EtaHadGEM2-ES apresentou maior redução da precipitação em ambos os cenários radiativos, com uma redução anual de 17,4\% (RCP4.5) e 32.3\% (RCP8.5), enquanto o Eta-CanESM2 indicou maior aquecimento, com um aumento anual de $4,7{ }^{\circ} \mathrm{C}$ e $10,2^{\circ} \mathrm{C}$ para $\mathrm{RCP} 4.5$ e $\mathrm{RCP} 8.5$, respectivamente. Assim como as mudanças de precipitação, o Eta-HadGEM2-ES também mostrou maiores impactos na vazão sob o RCP4.5 no primeiro intervalo de clima (2011-2040), com redução anual de 58,0\% para ambos os modelos hidrológicos, e para o cenário RCP8.5 no final do século (2071-2099), com redução anual de 54,0 (modelo VIC) e 56,8\% (modelo SWAT). Na vazão mensal, as entradas do Eta-HadGEM2-ES e o Eta-CanESM2 indicaram queda no cenário RCP8.5 até o final do século, variando de 7,2 a 66,3\% (modelo VIC) e 37,0 a 64,7\% (modelo SWAT). Em geral, o Eta-MIROC5 apresentou o contrário em termos de direção nas simulações com os dois modelos hidrológicos no final do século. Efeitos combinados de modelos climáticos, estruturas de modelos hidrológicos e cenários de mudanças climáticas devem ser considerados nas avaliações de incertezas dos impactos das mudanças climáticas.

Palavras-chave: Eta-CanESM2, Eta-HadGEM2-ES, Eta-MIROC5, modelo SWAT, modelo VIC, mudanças climáticas.

\section{INTRODUCTION}

Climate change and human activity influence hydrological processes, causing critical impacts on both the dynamics of ecosystems and society, and affect urban water supply systems, irrigated agriculture, and hydropower production (Viola et al., 2014; Oliveira et al., 2017; Byun et al., 2019).

The upper Rio Grande Basin, located in southern Minas Gerais state, has great relevance in water availability and hydropower production, contributing also to the Furnas hydropower plant reservoir (Pinto et al., 2019; Oliveira et al., 2017). Thus, the investigation of regional variations caused by climate change are important for water-resource management, agricultural and energy production, water availability, and forecasting of flooding and drought (Byun et al., 2019).

In South America, some studies (Chou et al., 2014; Ribeiro Neto et al., 2016; Oliveira et al., 2017) evaluated projections Eta driven by HadGEM2 and MIROC5, for two scenarios (RCP4.5 and RCP8 .5). These studies indicated an increase in temperature and a reduction in precipitation, mainly in the central and southeastern regions of Brazil, a fact that may indicate a considerable reduction in streamflow and hence in the potential for energy generation, throughout the 21st century. In addition, it was found in these studies that Eta-HadGEM2-ES is more sensitivity in these changes than the Eta-MIROC5.

Alvarenga et al. (2018) evaluated the impact of climate change on the hydrologic components in a watershed located in Mantiqueira Range, southern Minas Gerais state. The authors used the Distributed Hydrology Soil Vegetation Model (DHSVM) hydrological model forced by Eta-HadGEM2-ES under RCPs 4.5 and 8.5, finding a reduction in mean seasonal 
streamflow for all future periods and both emission radiative scenarios. The authors showed that most critical situations occur during the summer (December to February) from 2011 to 2040 under RCP4.5 and 2071 to 2099 under RCP8.5.

These studies evaluated the hydrological impacts in Brazilian basins using downscaling projections from different climate models and scenarios; however, they were limited to one hydrological model. Projections based on one hydrological model may be highly uncertain, while application of different models can show the sources of uncertainties. The more comprehensive the study in sampling uncertainties, the higher its quality (Hattermann et al., 2017; Teklesadik et al., 2017; Krysanova et al., 2018).

Hydrological models can show similar performance during calibration; however, the mean discharge response to climate change may vary due to dissimilarities in hydrological model structure and process equations. In addition, there is a cascade of uncertainty in climate change impact assessment that begins with the construction of future climate scenarios and ends in impact assessment (Bastola et al., 2011; Krysanova et al., 2017). Mach et al. (2017) also highlights the attention in the bias correction, because uncertainties are recognized in the downscaling models. Thus, the use of an ensemble of climate models and a variety of scenarios should be considered to represent a range of impacts.

In this context, the objective of this research was to compare climate change responses in the Verde River Basin, southeast Brazil, using two hydrological models: Variable Infiltration Capacity (VIC) that divides the basin into regular grid cells, and Soil and Water Assessment Tool (SWAT) that disaggregate a basin into subbasins and hydrological response units based on land use, topography and soil classes. The projection data are downscaling of three GCMs (CanESM2, HadGEM2 and MIROC5) by the RCM Eta under two future scenarios (RCP4.5 and RCP8.5). The novelty herein is the application of mesoscale (SWAT) and macroscale (VIC) hydrological models for assessment of climate change on a mesoscale basin, and evaluation of the impacts projected by climate models in the Verde River Basin.

\section{MATERIAL AND METHODS}

\subsection{Study area}

The Verde River Basin (VRB) has a drainage area of approximately $4,100 \mathrm{~km}^{2}$, with an elevation ranging from 809 to $2742 \mathrm{~m}$, and is located in the Mantiqueira Range region, the headwater of the Grande River Basin (GRB), southern Minas Gerais state (Figure 1). The GRB is an important Brazilian river for hydroelectric energy production (Oliveira et al., 2018; Viola et al., 2014). According to the Köppen classification, the climate in this region is mostly $C w b$ (Alvares et al., 2014), the mean annual precipitation is approximately $1500 \mathrm{~mm}$, and the annual mean temperature is $18^{\circ} \mathrm{C}$, with a dry winter season (Mello et al., 2012).

\subsection{Data}

The SWAT and VIC hydrological models were used to simulate the monthly streamflow under RCP4.5 and RCP8.5 scenarios, obtained by Regional Climate Models Eta-HadGEM2ES, Eta-CanESM2 and Eta-MIROC5 in the baseline period (1961-2005) and three time-slices (2011-2040, 2041-2070, and 2071-2099) inputs.

The SWAT is a hydrological model of spatial scale that is continuous, physically-based and semi-distributed in space, which divides the basin into sub-basins connected by a stream network. Land cover, soil type and slope information are combined into hydrological response units (HRUs) consisting of lumped land areas (Arnold et al., 1998). The SWAT was developed to estimate the impact of soil management practices on water, sediment and agricultural chemical productions in large complex river basins with different soil types, soil use and management conditions over long periods of time (Neitsch et al., 2005). 


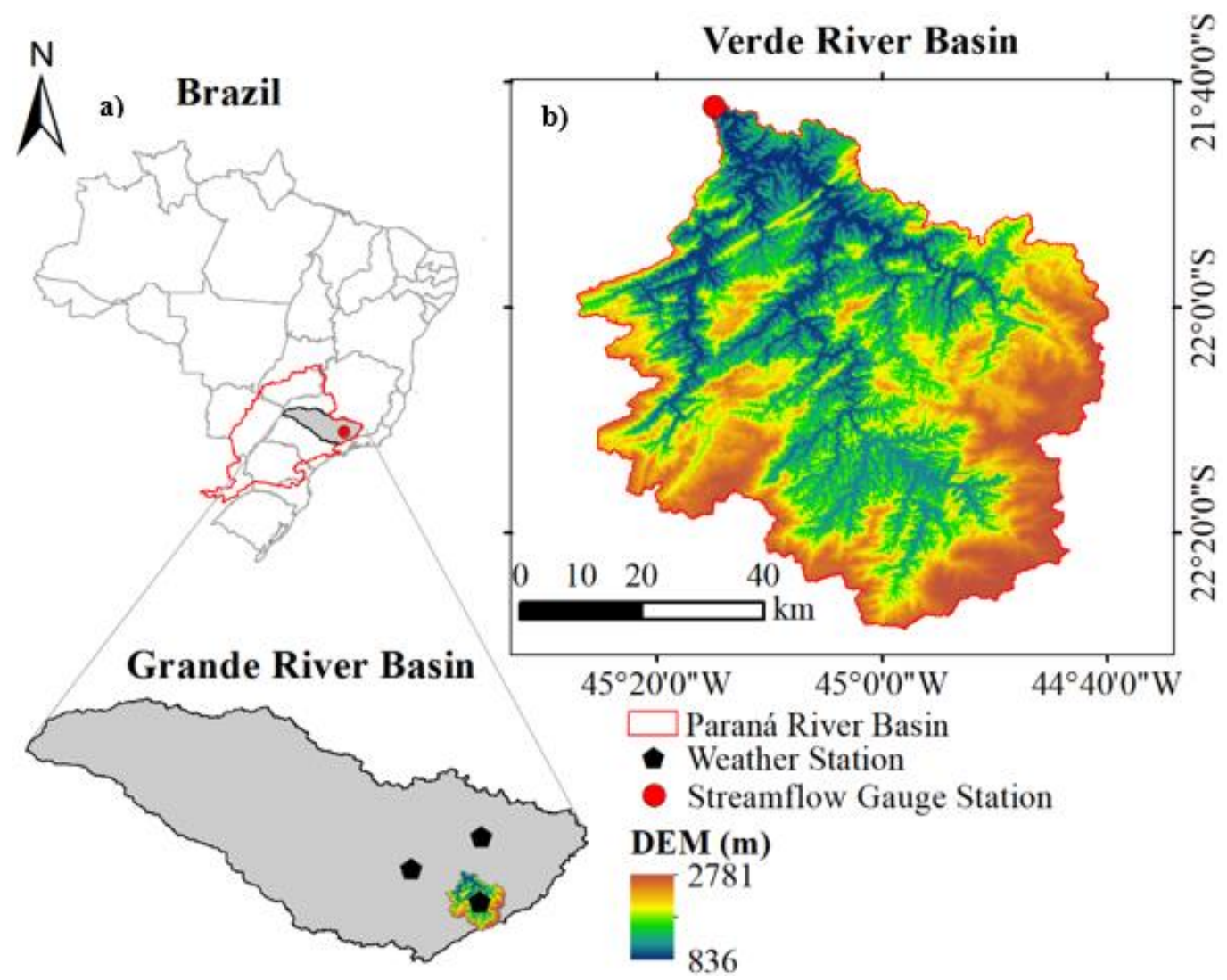

Figure 1. Geographical location of the VRB in the Grande River Basin (GRB), Minas Gerais state, southeast Brazil (a), and its Digital Elevation Model (DEM) (b).

The SWAT simulations on the hydrology module are based on water balance (Equation 1), calculated using hydrological routines that calculate the components of the water cycle, such as surface and groundwater flows, canopy storage, evapotranspiration, percolation, lateral flows, and transmission losses. Thus, runoff is calculated for each HRU and routed to estimate streamflow in each sub-basin.

$S W_{t}=S W_{0}+\sum_{i=1}^{t}\left(R-Q_{\text {surf }}-E_{a}-w_{\text {seep }}-Q_{g w}\right)$

Where $S W_{t}$ and $S W_{0}$ are, respectively, final and initial soil water content, $t$ is the time, $R$ is the precipitation, $Q_{\text {surf }}$ is the surface streamflow, $E_{a}$ is the evapotranspiration, $w_{\text {seep }}$ is the percolation and bypass flow, and $Q_{g w}$ is the groundwater flow.

The surface flow is calculated by either the SCS Curve Number procedure (Mockus, 1964) using daily precipitation data, or by the Green and Ampt infiltration method (Green and Ampt, 1911). Evapotranspiration is estimated by Penman-Montheith (Montheith, 1965), PriestleyTaylor (Priestley and Taylor, 1972) or Hargreaves (Hargreaves et al., 1985) methods, varying the required meteorological inputs for each method. In this study, the SCS curve number and Penman-Montheith methods were adopted. More details about SWAT theoretical equations can be found in Neitsch et al. (2011) and Arnold et al. (1998).

The VIC model is a grid-based macroscale semi-distributed land surface hydrological model, which consists of two modules: (i) rainfall-runoff (Liang et al., 1994, 1996; Liang and Xie, 2001) that simulates the water and energy fluxes that govern the terrestrial hydrological cycle; and (ii) routing model (Lohmann et al., 1996, 1998) that calculates the discharge using linearized de Saint-Venant equations. 
In the upper soil layer, the variable soil moisture capacity curve (Equation 2) controls evaporation, infiltration, and surface runoff; while the lower layer controls the baseflow generation, using the ARNO formulation (Todini, 1996). The evapotranspiration (vegetation transpiration, canopy evaporation, and evaporation from bare soil) is based on the PenmanMonteith equation.

$\mathrm{i}=\mathrm{i}_{\mathrm{m}} *\left[1-(1-\mathrm{A})^{1 / \mathrm{b}_{\mathrm{i}}}\right]$

Where $i$ and $i_{m}$ are the point and maximum point soil moisture capacity, respectively; $A$ is the fraction of an area for which the soil moisture capacity is less than or equal to $i$; and $b_{i}$ is the soil moisture capacity shape parameter.

VIC model was manually calibrated using a spatial resolution of $0.01^{\circ}$ with a total of 3728 grid cells and was carried out by adjusting the parameters described: i) infiltration parameter (b_infilt) describes the amount of available infiltration capacity as a function of relative saturated gridcell area. A higher value of b_infilt gives lower infiltration and yields higher surface runoff; ii) thickness of the third soil layer (depth_3), interfering in the transpiration (depending on root depth) and baseflow. Where thick layers of soil have slower runoff responses (predominance of baseflow) and high evapotranspiration, however, the result is high moisture retention and high baseflow in dry periods; iii) maximum baseflow that can occur from the lowest soil layer (Ds); and iv) fraction of the maximum soil moisture (Ws). A higher value of Ws will raise the water content required for rapidly increasing, non-linear baseflow, which will tend to delay runoff peaks. In addition to the calibration of the VIC model, the parameters of the surface-flow propagation model (Route) were also refined (kinematic wave speed (C) and diffusivity (D)) (Alvarenga et al., 2020).

While the SWAT model was calibrated using the Sequential Uncertainty Fitting Algorithm (SUFI2) implemented in SWATCUP by Abbaspour et al. (2007), with a total of 57 sub-basins and 1503 HRUs. The calibration was done by adjusting 14 parameters that represent the surface and subsurface flow processes. These parameters are: soil evaporation compensation coefficient (ESCO); initial SCS runoff curve number for moisture condition II (CN2); the baseflow recession constant (ALPHA_BF), Groundwater delay time (GW_DELAY); threshold depth of water in the shallow aquifer required for return flow to occur (GWQMN); maximum canopy storage (CANMX); effective hydraulic conductivity in main channel (CH_K2), Manning's "n" value for the main channel (CH_N2); plant uptake compensation factor (EPCO); groundwater "revap" coefficient (GW_REVAP); threshold depth of water in the shallow aquifer for "revap" or percolation to the deep aquifer to occur (REVAPMN); soil available water capacity (SOL_AWC); saturated hydraulic conductivity (SOL_K) and surface runoff lag coefficient (SURLAG) (Alvarenga et al., 2020).

Information from the ASTER sensor with a resolution of 1 arc-second ( $30 \times 30$ meters) was used to obtain the Digital Elevation Model (DEM) (Figure 1); images of the LANDSAT 8 sensor with a resolution of 1 arc-second were used to obtain the land-use map through supervised and object-oriented classification techniques; and soil class mapping was provided by State Foundation for the Environment (FEAM, 2010). The atmospheric variables were obtained from the meteorological stations from National Institute of Meteorology, and observed streamflow from the water level station at Três Corações, obtained from the National Water Agency (Figure 1). The hydrological models are run for the period 1990-2005: first 3-yrs were used for warm up, 1993 to 1999 calibration period, and 2000 to 2005 for validation period.

Four statistical indices were calculated in the performance assessment: (i) coefficient of determination $\left(\mathrm{R}^{2}\right)$ that is used to describe the variance between simulated and observed streamflow; (ii) Nash-Sutcliffe efficiency coefficient (CNS) that is used to reflect the matching degree between simulated and observed streamflow (Nash and Sutcliffe, 1970); (iii) Nash- 
Sutcliffe efficiency of the logarithmic values of streamflow (CNS Log) that is used to assess the model performance during recession period; and (iv) Relative error (Pbias) that is employed to measure the mean tendency of the difference between simulated and observed streamflow (Gupta, 1999). According to Moriasi et al. (2007), the $R^{2}$ and $C N S$ values above 0.50 are considered acceptable, and Pbias less than $|25 \%|$ present satisfactory results. CNS Log values from 0.35 to 0.50 and 0.5 to 0.7 indicate medium and good hydrological model performance, respectively.

\subsection{Climate Models, Downscaling and Bias Correction}

To meet the goals of this study, two hydrological models (SWAT and VIC) will be created with results from three climate models and two emission radiative scenarios. The climate simulations used in this work were based on the dynamical downscaling of the CanESM2, HadGEM2-ES and MIROC5 global climate model (GCMs) simulations using the Eta regional climate model (Chou et al., 2012; Marengo et al., 2012; Mesinger et al., 2012; Pesquero et al., 2010). These 3 models were recommended for the assessment of climate change projections in South America (Dereczynski et al., 2020).

The main characteristics of the GCMs are summarized in Table 1. The chosen emission radiative scenarios were: RCP4.5 that is a medium-to-low scenario, assuming a stabilization of radiative forcing to $4.5 \mathrm{~W} \mathrm{~m}^{-2}$ by 2100 ; and RCP8.5 that is the most pessimistic situation, with radiative forcing to $8.5 \mathrm{~W} \mathrm{~m}^{-2}$ by 2100 .

Table 1. Global Climate Models CanESM2, HadGEM2 and MIROC5.

\begin{tabular}{|c|c|c|c|}
\hline Global Climate Model & Reference & $\begin{array}{l}\text { Horizontal Resolution } \\
\text { (atmospheric } \\
\text { component) }\end{array}$ & $\begin{array}{l}\text { Levels in } \\
\text { Vertical }\end{array}$ \\
\hline $\begin{array}{l}\text { CanESM2 -ES-Canadian Earth } \\
\text { System Model version } 2\end{array}$ & $\begin{array}{l}\text { Arora et al. } \\
\quad(2011)\end{array}$ & $\begin{array}{l}2.75^{\circ} \text { (latitude) and } \\
2.8125^{\circ} \text { (longitude) }\end{array}$ & 35 \\
\hline $\begin{array}{l}\text { HadGEM } 2 \text { - Hadley Centre Global } \\
\text { Environmental Model version } 2\end{array}$ & $\begin{array}{l}\text { Collins et al. } \\
\text { (2011) and } \\
\text { Martin et al. } \\
\quad(2011)\end{array}$ & $\begin{array}{l}1.274^{\circ} \text { (latitude) and } \\
1.875^{\circ} \text { (longitude) }\end{array}$ & 38 \\
\hline $\begin{array}{l}\text { MIROC5 - Model for } \\
\text { Interdisciplinary Research on } \\
\text { Climate version } 5\end{array}$ & $\begin{array}{l}\text { Watanabe } \text { et al. } \\
\quad \text { (2010) }\end{array}$ & $150 \mathrm{Km}$ & 40 \\
\hline
\end{tabular}

The downscaling method provided simulations with spatial resolution of $20 \mathrm{~km}$, covering the following periods: 1961 to 2005 for baseline, and 2011 to 2099 for future scenarios (RCP4.5 and RCP8.5) that were divided into three time-slices (2011-2040, 2041-2070, and 2071-2099). The monthly variables simulated by Eta model used to assess the potential hydrological impacts on the VRB were precipitation, maximum and minimum temperatures, solar radiation, relative humidity, and wind speed.

However, simulations from RCMs, such as Eta, are subjected to systematic biases (Graham et al., 2007; Rodrigues et al., 2020), mainly caused by errors in conceptualization, discretization and spatial average of climate variables within a grid-cell (Teutschbein and Seibert, 2012). 
Therefore, the RCM variables biases were corrected based on observed meteorological data, wherein the linear scaling method was used for precipitation, maximum and minimum temperatures as proposed by Lenderink et al. (2007), and for wind speed as proposed by Haddeland et al. (2012).

\section{RESULTS AND DISCUSSION}

The coupled simulations are referred to as Eta-HadGEM2-ES-ES, Eta-CanESM2, and EtaMIROC5, when the Eta model is driven by HadGEM2-ES, CanESM2, and MIROC5, respectively. The variations and the changes are based on comparisons between future scenarios (RCP4.5 and RCP8.5) and baseline period for each RCM. In this study, the wet season is from October to March, while the dry season is from April to September.

\subsection{Models Performance}

Hydrological models were calibrated and validated to the monthly observed streamflow in the Verde River Basin by Alvarenga et al. (2020). Figure 2 shows the monthly mean hydrographs for the SWAT and VIC in the calibration and validation periods, indicating better performance for peak streamflow simulated for VIC, while SWAT was able to capture the behavior of the recession period in the VRB. In research in the Grande River Basin headwater, Viola et al. (2014) and Oliveira et al. (2018), using LASH and SWAT models, respectively, also showed underestimation of simulated streamflow during the validation period. These problems tend to get worse with an increasing number of parameter values. Additionally, in the same region, Alvarenga et al. (2016), applying the DHSVM model, presented underestimation during the dry season and overestimation during the wet season.

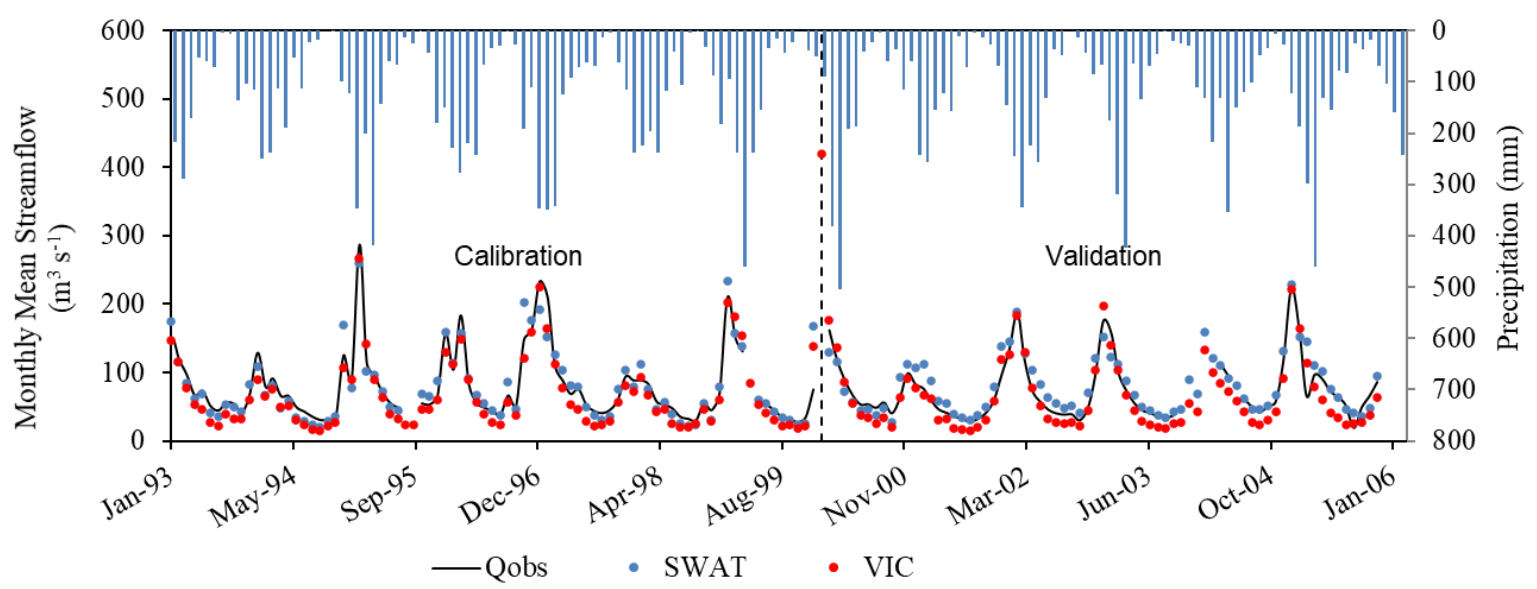

Figure 2. Observed and simulated monthly mean streamflow during the calibration and validation periods by SWAT and VIC models in the Rio Verde Basin.

Table 2 shows statistical indices from the comparison between observed and simulated monthly streamflow by the SWAT and VIC models. According to Moriasi et al. (2007), the statistical indices showed satisfactory performances predicting the monthly streamflow from VRB, with $R^{2}$ and $C N S$ values above 0.50, Pbias less than |25\%|, and CNS Log values above 0.4 . However, the lower CNS Log value showed poor VIC model performance in the recession period. 
Table 2. Statistics of precision for SWAT and VIC models for the monthly mean streamflow in the VRB.

\begin{tabular}{ccccc}
\hline \multirow{2}{*}{ Statistical Indices } & \multicolumn{2}{c}{ Calibration } & \multicolumn{2}{c}{ Validation } \\
\cline { 2 - 5 } & SWAT & VIC & SWAT & VIC \\
\hline CNS & 0.86 & 0.86 & 0.81 & 0.83 \\
CNS Log & 0.84 & 0.54 & 0.78 & 0.42 \\
$R^{2}$ & 0.87 & 0.92 & 0.84 & 0.93 \\
Pbias (\%) & 0.45 & 14.81 & -8.29 & 13.88 \\
\hline
\end{tabular}

\subsection{Climate Model Projections}

Figure 3 shows monthly changes of precipitation and maximum and minimum temperatures projected by RCMs (Eta-CanESM2, Eta-HadGEM2-ES and Eta-MIROC5) for three time-slices (2011-2040, 2041-2070, and 2071-2099) and under RCP4.5 and RCP8.5 scenarios, relative to the baseline period (from 1961 to 2005).
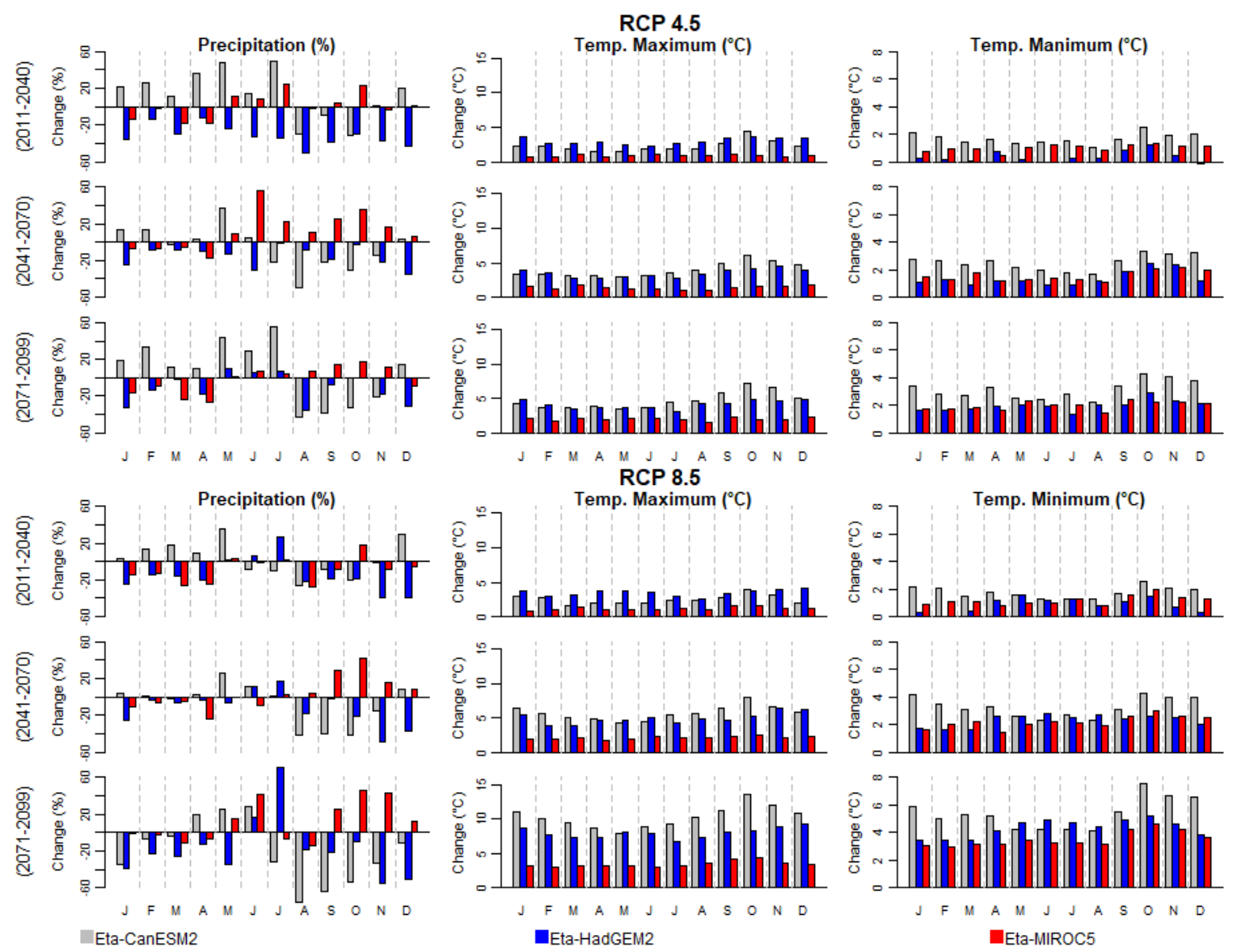

Figure 3. Monthly changes of precipitation and temperature (maximum and minimum) relative to baseline (1961-2005) projected by the RCMs Eta-CanESM2 (grey), Eta-HadGEM2-ES (blue) and Eta-MIROC5 (red) for three time-slices (2011-2040, 2041-2070 and 2071-2100), under RCP4.5 and RCP8.5, in the VRB. 
The projected changes in monthly precipitation differed among the models, both in terms of the magnitude and in the signal of changes (Figure 3). The precipitation simulations show the greatest decrease of the annual rainy for Eta-HadGEM2-ES when compared to EtaMIROC5 and Eta-CanESM2 under RCP4.5 and RCP8.5 scenarios.

At the beginning of the 21st century (2011-2040), the Eta-HadGEM2-ES showed a decrease of 32.2 and $23.3 \%$ in the annual precipitation under RCP4.5 and RCP8.5, respectively; this situation is also observed at the end of the 21st century (2071-2099), indicating a reduction of 17.4 and $32.3 \%$ for RCP4.5 and RCP8.5, respectively. In general, the Eta simulations driven by HadGEM2-ES presented greater decreases during the wet season (October to March period) when compared to the baseline period; whereas June and July, for the third time-slice, revealed an increase of 5.5 and $7.3 \%$ for RCP4.5, and 16.2 and 70.5\% under RCP8.5, respectively.

Overall, the Eta-HadGEM2-ES produces more precipitation than Eta-MIROC5 during the dry season, and less during the wet season. This behavior can explain the minor decrease in the annual precipitation with Eta-MIROC5 when compared to Eta-HadGEM2-ES. These results are similar to those presented by Chou et al. (2014) in the Central-South region of Brazil, by Lyra et al. (2017) in Central America, and by Alvarenga et al. (2018) and Oliveira et al. (2017) in the Grande River Basin headwater.

Considering the Eta-HadGEM2-ES, Oliveira et al. (2017) observed a reduction in mean annual precipitation of 2.2 and $28.1 \%$ for RCPs 4.5 and 8.5, respectively; while regarding the Eta-MIROC5 model, there was an attenuation of 7.5 and $1.2 \%$ for RCPs 4.5 and 8.5, respectively. Alvarenga et al. (2018) showed a negative trend in the summer season (December to February) in the same scenarios and Eta-HadGEM2-ES simulations toward the end of the century.

These uncertainties and significant differences also may be attributed to the different setup of GCMs and resolution of RCM Eta, generating responses that diverge in both precipitation forecasting and impacts caused by future scenarios. According to Alvarenga et al. (2018) who used the Eta-5km resolution, the high-resolution $(5 \mathrm{~km})$ of Eta may capture topographic features and extreme values better when compared with low-resolution $(20 \mathrm{~km})$.

The effect of increased mean maximum and minimum temperature is evident for three RCMs and in all future scenarios. The Eta-CanESM2 presented greater changes in the monthly maximum and minimum temperatures, with an increase of 7.2 and $4.3^{\circ} \mathrm{C}$, respectively, under RCP4.5; and an increase of 13.6 and $7.5^{\circ} \mathrm{C}$ under RCP8.5, respectively. The Eta-MIROC5 and Eta-HadGEM2-ES showed less increase in the values of temperatures, with an increase of 2.2 and $4.8^{\circ} \mathrm{C}$ in the maximum temperature, and 2.4 and $2.9^{\circ} \mathrm{C}$ in the minimum temperature under RCP 4.5; and an increase of 4.3 and $9.2^{\circ} \mathrm{C}$ in the maximum temperature, and 4.6 and $5.2^{\circ} \mathrm{C}$ in the minimum temperature, under RCP 8.5 (Figure 3).

\subsection{Monthly Streamflow Changes}

Figure 4 shows mean monthly hydrographs simulated by SWAT and VIC models for RCMs Eta-CanESM2, Eta-HadGEM2-ES and Eta-MIROC5 during baseline period (grey) and three time-slices (2011-2040, 2041-2070 and 2071-2100), under RCP4.5 (blue) and RCP8.5 (red).

At the end of the century, the SWAT and VIC model impacts presented similar behaviors in the monthly streamflow in the Eta-HadGEM2-ES, with a decrease varying from 31.9 to $47.0 \%$ (RCP4.5) and from 37.0 to $64.7 \%$ (RCP8.5) in the simulations with SWAT, and ranging from 15.1 to $58.4 \%$ (RCP4.5) and from 44.0 to $61.2 \%$ (RCP8.5) in the simulations with VIC. Both hydrological models did not show noticeable differences between the monthly streamflow when compared to the baseline period. 

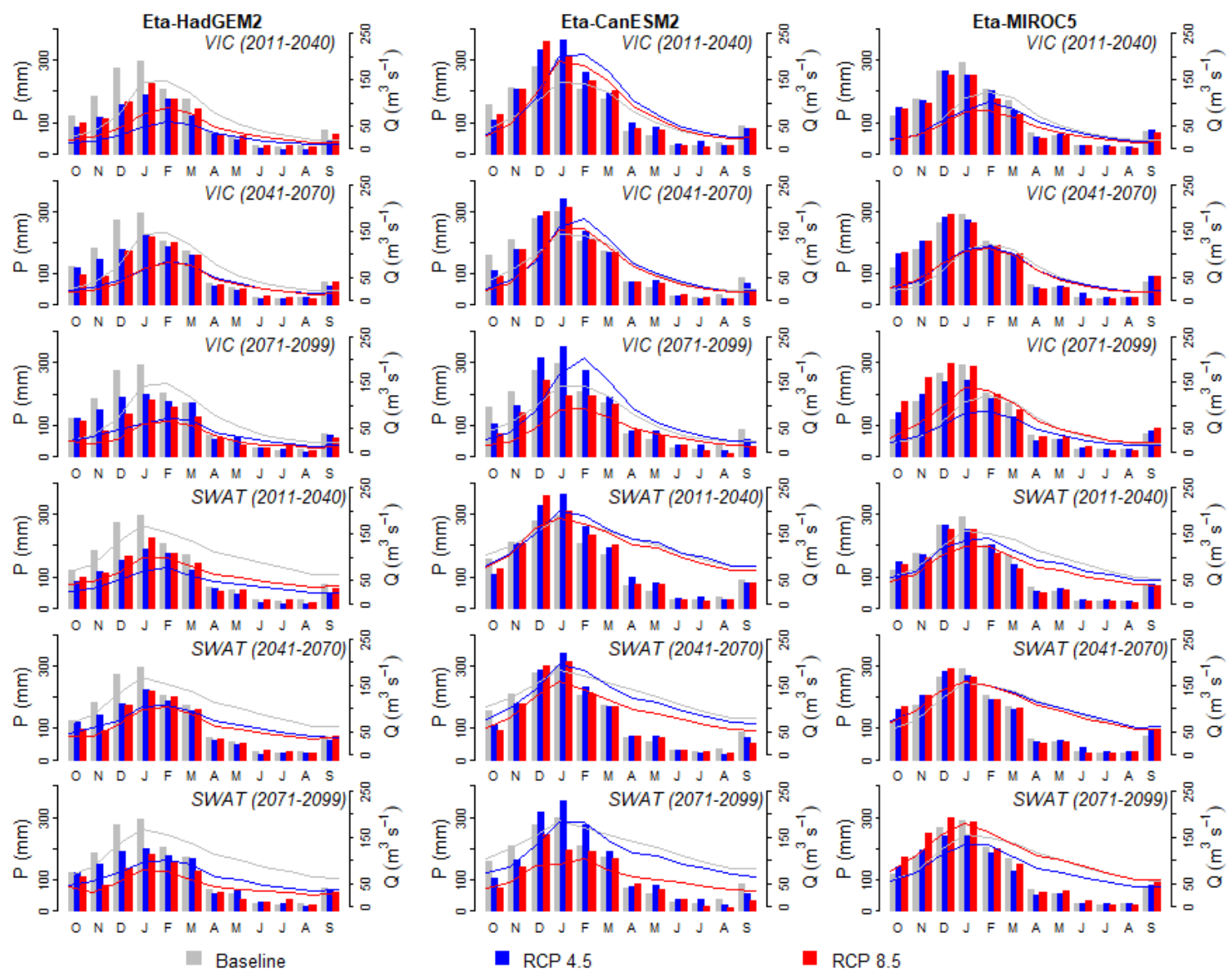

RCP 8.5

Figure 4. Mean monthly 10nual10itation (P) and streamflow (Q) simulated by SWAT and VIC models for RCMs Eta-CanESM2, Eta-HadGEM2-ES and Eta-MIROC5 during baseline period (grey) and three time-slices (2011-2040, 2041-2070 and 2071-2100), under RCP 4.5 (blue) and RCP 8.5 (red). Continuous line and bar are mean monthly streamflow and 10nual10itation, respectively.

Regarding 10nual mean streamflow under Eta-HadGEM2-ES, from 2011 to 2040, 2041 to 2070 , and 2071 to 2099 , the VIC model simulations presented a reduction of 57.8, 39.3 and $42.5 \%$ under the RCP4.5 scenario, respectively; and 38.3, 41.3 and 54.0\% under the RCP8.5 scenario, respectively. The SWAT model also indicated a reduction in these time-slices of 58.0, 35.2 and 40.5\% under RCP4.5, respectively; and 42.1, 42.1 and 56.8\% under RCP8.5, respectively (Figure 5). In agreement with these results, Alvarenga et al. (2018) and Oliveira et al. (2017), also reported that the Eta model driven by HadGEM2-ES indicated greater changes at the beginning of the 21 st century under RCP4.5, while RCP8.5 presented greater changes at the end the 21 st century.

On the other hand, the SWAT and VIC simulations with Eta-MIROC5 presented a different behavior in relation to Eta-HadGEM2-ES. At the end of the century, considering the SWAT model, the mean annual streamflow decreased $17.5 \%$ (RCP 4.5) and increased 10\% (RCP 8.5); additionally, the VIC model indicated a decrease of $23.6 \%$ under RCP 4.5 and an increase of $15.8 \%$ under RCP 8.5. Under the RCP8.5 scenario, the increase took place mainly in the wet season (October to January) in both hydrological models. However, from January through September there was a reduction of streamflow under RCP4.5 in both hydrological models. Regarding Eta-MIROC5, Oliveira et al. (2017), also by the end of the century, showed a reduction and increase of the streamflow simulations under RCP4.5 and RCP8.5 scenarios, respectively, especially in the wet season (October to January). 

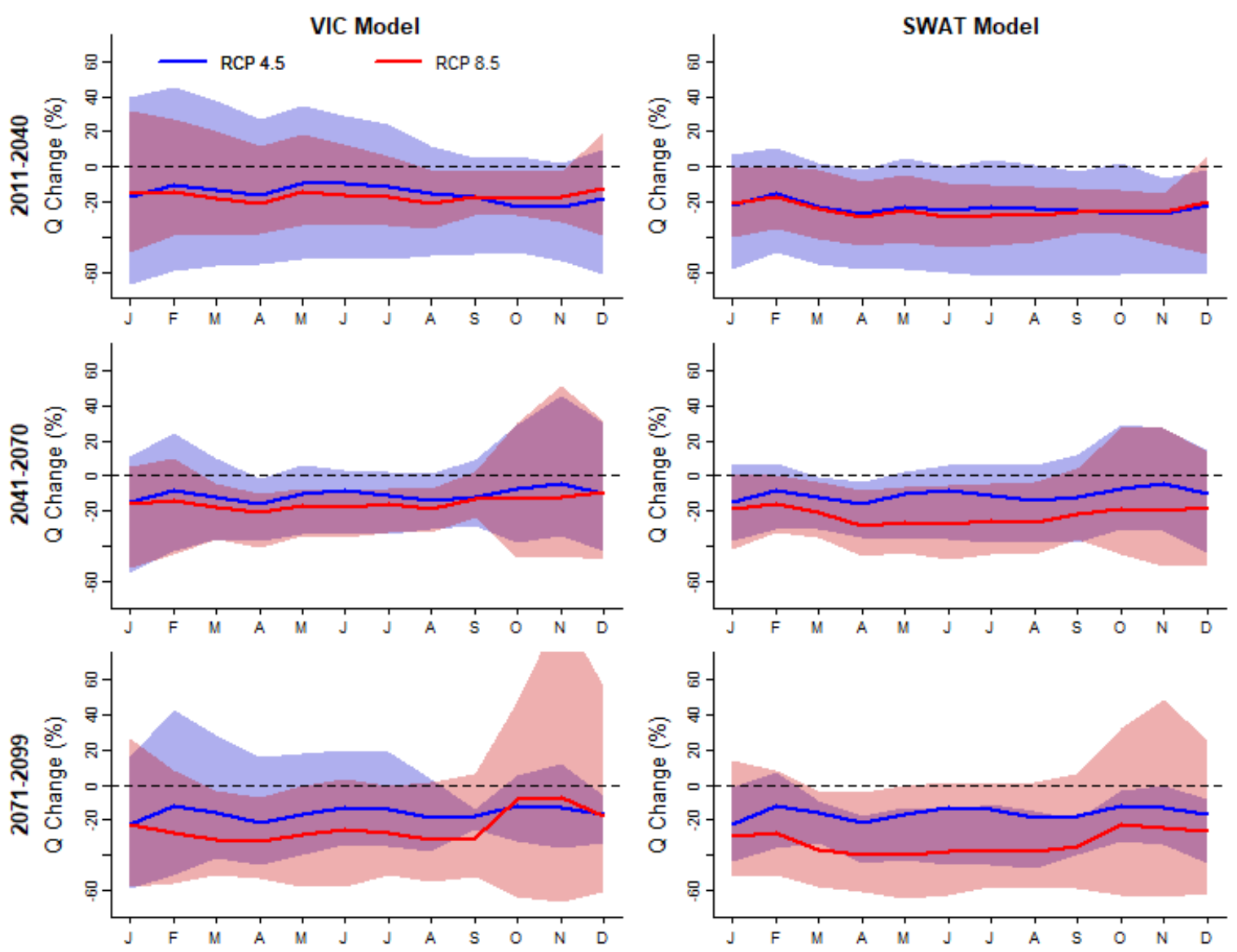

Figure 5. Ensembles mean of monthly changes (\%) on the streamflow (Q) of three RCMs. Each shaded range is bounded by minimum and maximum of three RCMs under RCP4.5 (blue) and RCP8.5 (red).

The largest differences in streamflow simulations were observed with the Eta-CanESM2. The SWAT model showed, in the annual mean streamflow, a decrease of $12.6 \%$ (RCP 4.5) and $51.5 \%$ (RCP 8.5 ) at the end of the century. In the same period, the VIC model indicated a reduction of $39.6 \%$ under RCP8.5 and an increase of $12.1 \%$ under RCP4.5, which occurred between January and August.

Figure 5 shows projected changes (ensemble mean) of the mean monthly streamflow for three time-slices (2011-2040, 2041-2070 and 2071-2100) in relationship to the baseline period (from 1961 to 2005).

At the beginning of the century, both hydrological models presented low variability in the streamflow changes in the future scenarios (RCP4.5 and RCP8.5). The changes can be seen clearly at the end of the century for the RCP8.5 scenario, when compared to the RCP4.5 scenario (Figure 5).

Hydrological model simulations showed little variation between streamflow outputs. The ensembles mean of the SWAT model indicated a reduction in the streamflow ranging from 13.2 to $30.0 \%$ and 22.3 to $40.0 \%$ under RCP4.5 and RCP8.5, respectively, by the end of the century. The VIC model also showed a decrease in the streamflow varying from 12.0 to $22.2 \%$ (RCP4.5) and 7.5 to $31.9 \%$ (RCP8.5). The SWAT model indicates noticeable changes, although it showed a smaller amplitude of monthly maximum and minimum values of streamflow, mainly under RCP 4.5 (Figure 5).

In general, the predicted average streamflow is relatively closer in the hydrological model responses. However, the amplitude of the simulated streamflow is higher in VIC compared to SWAT. These sharp differences in the output hydrological models can be characterized by 
seasonal variability in rainfall. Mainly in the rainy season, VIC was more sensitive to peak streamflows, while SWAT reduces maximum and minimum streamflows. The main differences in the streamflow simulations during the rainy season are harmful for agriculture and energy generation in the region. The difference in the parameterization and structure of the hydrological models provided different results of impacts on the average monthly streamflow of the Rio Verde Basin, i.e., the model affects the result of the impact analysis.

\section{CONCLUSIONS}

SWAT and VIC models were not calibrated using similar methods, but showed similar performance during calibration according to the statistical precision indices. The hydrological models driven by the RCMs Eta-CanESM2, Eta-HadGEM2-ES and Eta-MIROC5 simulated the monthly streamflow in the Verde River Basin under the influence of RCP4.5 and RCP8.5 scenarios.

There is an overall consensus among all three climate models of a projected maximum and minimum temperature increase in the area. The largest increases occur at the end of the century for all models. The monthly changes in maximum and minimum temperature are noticeably larger for the Eta-CanESM2 than for Eta-HadGEM2-ES and Eta-MIROC5 in the third timeslice, under RCP8.5. In contrast, the monthly changes of precipitation are highly dissimilar among climate models.

Regarding monthly streamflow, both hydrological models showed an increase from October to January for the Eta-MIROC5 under RCP8.5, being more significant in November, with an increase of 49.1 and $99.8 \%$ for SWAT and VIC models, respectively. The EtaHadGEM2-ES and Eta-CanESM2 indicated reduction of streamflow in all months and in both hydrological models, except Eta-CanESM2 under RCP4.5 for VIC model simulations that showed an increase ranging from 3.8 to $42.5 \%$ between January and August, and a decrease varying from 10.7 to $35.4 \%$ between September and December.

This study highlights sources of uncertainty, such as emission/radiative forcing scenarios, downscaling, bias correction, climate modeling, and hydrological modeling. The results suggest that climate models represent the major source of uncertainty in the simulations. However, the water availability reduction results obtained in the hydrological modeling can cause collapse in both hydropower generation and food production in this region and these impact studies of the hydrological response are important for local communities.

\section{ACKNOWLEDGEMENTS}

The authors would like to thank Conselho Nacional de Desenvolvimento Científico e Tecnológico for financing this study (Process 429247/2018-4).

\section{REFERENCES}

ABBASPOUR, K. C.; YANG, J.; MAXIMOV, I.; SIBER, R.; BOGNER, K.; MIELEITNER, J.; et al. Modelling hydrology and water quality in the pre-alpine/alpine Thur watershed using SWAT. Journal of Hydrology, v. 333, p. 413-430, 2007. https://doi.org/10.1016/j.jhydrol.2006.09.014

AlVARENGA, L. A.; MEllo, C. R.; COlOMBO, A.; CUARTAS, L. A.; CHOU, S. C. Hydrological responses to climate changes in a headwater watershed. Ciência \& Agrotecnologia, v. 40, n. 6, p. 647-657, 2016. https://doi.org/10.1590/141370542016406027716 
ALVARENGA, L. A.; MELlO, C. R.; COLOMBO, A.; CHOU, S. C.; CUARTAS, L. A.; VIOLA, M. R. Impacts of climate change on the hydrology of a Small Brazilian headwater catchment using the distributed hydrology-soil-vegetation model. American Journal of Climate Change, v. 7, n. 2, p. 355-366, 2018. https://doi.org/10.4236/ajcc.2018.72021

ALVARENGA, L. A.; CARVALHO, V. S. O.; OlIVEIRA, V. A.; MELLO, C. R.; COLOMBO, A.; TOMASELLA, J. et al. Hydrological simulation with SWAT and VIC Models in the Verde River Watershed, Minas Gerais. Revista Ambiente \& Água, v. 15, n. 4, 2020. https://doi.org/10.4136/ambi-agua.2492

ALVARES, C. A.; STAPE, J. L.; SENTELHAS, P. C.; GONÇALVES, J. L. M.; SPAROVEK, G. Koppen's climate classification map for Brazil. Meteorologische Zeitschrift, v. 22, n. 6, p. 711-728, 2014. https://dx.doi.org/10.1127/0941-2948/2013/0507

ARNOLD, J. G.; SRINIVASAN, R.; MUTTIAH, R. S.; WILLIAMS, J. R. Large area hydrologic modeling and assessment part I: model development. Journal of the American Water Resources Association, v. 34, n. 1, p. 73-89, 1998. https://doi.org/10.1111/j.1752-1688.1998.tb05961.x

ARORA, V. K.; SCINOCCA, J. F.; BOER, G. J.; CHRISTIAN, J. R.; DENMAN, K. L.; FLATO, G. M. et al. Carbon emission limits required to satisfy future representative concentration pathways of greenhouse gases. Geophysical Research Letters, v. 38, n. 5, 2011. https://doi.org/10.1029/2010GL046270

BASTOLA, S.; MURPHY, C.; SWEENEY, J., The role of hydrological modelling uncertainties in climate change impact assessments of Irish river catchments. Advances in Water Resources, v. 34, n. 5, p. 562-576, 2011. https://doi.org/10.1016/j.advwatres.2011.01.008

BYUN, K.; CHIU, C. M.; HAMLET, A. F. Effects of 21st century climate change on seasonal flow regimes and hydrologic extremes over the Midwest and Great Lakes region of the US. Science of the Total Environment, v. 650, n. 1, p. 1261-1277, 2019. https://doi.org/10.1016/j.scitotenv.2018.09.063

CHOU, S. C.; MARENGO, J.; LYRA, A. A.; SUEIRO, G.; PESQUERO, J. F.; ALVES, L. M. et al. Downscaling of South America present climate driven by 4-member HadCM3 runs. Climate Dynamics, v. 38, p. 635-653, 2012. https://doi.org/10.1007/s00382-011-10028

CHOU, S. C.; LYRA, A.; MOURÃO, C.; DERECZYNSKI, C. P.; PILOTTO, I. L.; GOMES, J. L. et al. Assessment of climate change over South America under RCP 4.5 and 8.5 downscaling scenarios. American Journal of Climate Change, v. 3, n. 5, p. 512-527, 2014. https://dx.doi.org/10.4236/ajcc.2014.35043

COLLINS, W. J.; BELlOUIN, N.; DOUTRIAUX-BOUCHER, M.; GEDNEY, N.; HALLORAN, P.; HINTON, T. et al. Development and evaluation of an Earth-System model - HadGEM2. Geoscientific Model Development, n. 4, v. 4, p. 1051-1075, 2011. https://doi.org/10.5194/gmd-4-1051-2011

DERECZYNSKI, C., CHOU, S. C.; LYRA, A.; SONDERMANN, M.; REGOTO, P.; TAVARES, P. et al. Downscaling of climate extremes over South America-Part I: Model evaluation in the reference climate. Weather and Climate Extremes, v. 29, 100273, 2020. https://doi.org/10.1016/j.wace.2020.100273 
FEAM. Mapa de solos do Estado de Minas Gerais. Belo Horizonte, 2010. 49p.

GRAHAM, L. P.; ANDRÉASSON, J.; CARLSSON, B. Assessing climate change impacts on hydrology from an ensemble of regional climate models, model scales and linking methods - A case study on the Lule River basin. Climatic Change, v. 81, p. 293-307, 2007. https://doi.org/10.1007/s10584-006-9215-2

GREEN, W. H.; AMPT, G. A. Studies on soil physics. The Journal of Agricultural Science, v. 4, n. 1, p. 1-24, 1911. https://doi.org/10.1017/S0021859600001441

GUPTA, H. V.; SOROOSHIAN, S.; YAPO, P. O. Status of Automatic Calibration for Hydrologic Models: Comparison with Multilevel Expert Calibration. Journal of $\begin{array}{lllllll}\text { Hydrologic Engineering, } 1999 . & \text { v. 4, n. 2, p. 135-143, }\end{array}$ https://doi.org/10.1061/(ASCE)1084-0699(1999)4:2(135)

HADDELAND, I.; HEINKE, J.; VOß, F.; EISNER, S.; CHEN, C.; HAGEMANN, S. et al. Effects of climate model radiation, humidity and wind estimates on hydrological simulations. Hydrology and Earth System Sciences, v. 16, p. 305-318, 2012. https://doi.org/10.5194/hess-16-305-2012

HARGREAVES, G. L.; HARGREAVES, G. H.; RILEY, J. P. Agricultural benefits for senegal river basin. Journal of Irrigation and Drainage Engineering, v. 111, n. 2, p. 113-124, 1985. https://doi.org/10.1061/(ASCE)0733-9437(1985)111:2(113)

HATTERMANN, F. F.; KRYSANOVA, V.; GOSLING, S. N.; DANKERS, R.; DAGGUPATI, P.; DONNELLY, C. et al. Cross-scale intercomparison of climate change impacts simulated by regional and global hydrological models in eleven large river basins. Climatic Change, v. 141, n. 3, p. 561-576, 2017. https://doi.org/10.1007/s 10584-016$1829-4$

KRYSANOVA, V.; DONNELLY, C.; GELFAN, A.; GERTEN, D.; ARHEIMER, B.; HATTERMANN, F. et al. How the performance of hydrological models relates to credibility of projections under climate change. Hydrological Sciences Journal, v. 63, n. 5, p. 696-720, 2018. https://doi.org/10.1080/02626667.2018.1446214

KRYSANOVA, V.; VETTER, T.; EISNER, S.; HUANG, S.; PECHLIVANIDIS, I.; STRAUCH, M. et al. Intercomparison of regional-scale hydrological models and climate change impacts projected for 12 large river basins worldwide - a synthesis. Environmental Research Letters, v. 12, n. 10, 105002, 2017. https://doi.org/10.1088/1748-9326/aa8359

LENDERINK, G.; BUISHAND, A.; VAN DEURSEN, W. Estimates of future discharges of the river Rhine using two scenario methodologies: Direct versus delta approach. Hydrology and Earth System Sciences, v. 11, n. 3, p. 1145-1159, 2007. https://doi.org/10.5194/hess-11-1145-2007

LIANG, X.; LETTENMAIER, D. P.; WOOD, E. F.; BURGES, S. J. A simple hydrologically based model of land surface water and energy fluxes for general circulation models. Journal of Geophysical Research, v. 99, p. 14415-14428, 1994. https://doi.org/10.1029/94JD00483

LIANG, X.; WOOD, E. F.; LETTENMAIER, D. P. Surface soil moisture parameterization of the VIC-2L model: Evaluation and modifications. Global and Planetary Change, v. 13, p. 195-206, 1996. https://doi.org/10.1016/0921-8181(95)00046-1 
LIANG, X.; XIE, Z. A new surface runoff parameterization with sub grid-scale soil heterogeneity for land surface models. Advances in Water Resources, v. 24, p. 11731193, 2001. https://doi.org/10.1016/S0309-1708(01)00032-X

LOHMANN, D.; RASCHKE, E.; NIJSSEN, B.; LETTENMAIER, D. P. Regional scale hydrology: II. Application of the VIC-2L model to the Weser River, Germany. Hydrological Sciences Journal, v. 43, n. 1, p. 143-158, 1998. https://doi.org/10.1080/02626669809492108

LOHMANN, D.; NOLTE-HOLUBE, R.; RASCHKE, E. A large-scale horizontal routing model to be coupled to land surface parameterization schemes. Tellus, v. 48, n. 5, p. 708721, 1996. https://doi.org/10.3402/tellusa.v48i5.12200

LYRA, A.; IMBACH, P.; RODRIGUEZ, D.; CHOU, S. C.; GEORGIOU, S.; GAROFOLO, L. Projections of climate change impacts on central America tropical rainforest. Climatic Change, v. 141, n. 1, p. 93-105, 2017. https://doi.org/10.1007/s10584-016-1790-2

MACH, K. J.; MASTRANDREA, M. D.; FREEMAN, P. T.; FIELD, C. B. Unleashing expert judgment in assessment. Global Environmental Change, v. 44, p. 1-14, 2017.

MARENGO, J. A.; CHOU, S. C.; KAY, G.; ALVES, L. M.; PESQUERO, J. F.; SOARES, W. R. et al. Development of regional future climate change scenarios in South America using the Eta CPTEC/HadCM3 climate change projections: Climatology and regional analyses for the Amazon, São Francisco and the Paraná River basins. Climate Dynamics, v. 38, p. 1829-1848, 2012. https://doi.org/10.1007/s00382-011-1155-5

MARTIN, G. M.; BELLOUIN, N.; COLLINS, W. J.; CULVERWELL, I. D.; HALLORAN1, P. R.; HARDIMAN, S. C. et al. The HadGEM2 family of Met Office Unified Model climate configurations, Geoscientific Model Development, v. 4, p. 723-757, 2011. https://doi.org/10.5194/gmd-4-723-2011

MELLO, C. R.; NORTON, L. D.; CURI, N.; YANAGI, S. N. M. Sea Surface Temperature (SST) and rainfall erosivity in the Upper Grande River Basin, Southeast Brazil. Ciência \& Agrotecnologia, v. 36, n. 1, p. 53-59, 2012. https://doi.org/10.1590/S141370542012000100007

MESINGER, F.; CHOU, S. C.; GOMES, J. L.; JOVIC, D.; BASTOS, P.; BUSTAMANTE, J. F.; LAZIC, L.; LYRA, A. A.; MORELLI, S.; RISTIC, I.; VELJOVIC, K. An upgraded version of the Eta model. Meteorology and Atmospheric Physics, v. 116, p. 63-79, 2012. https://doi.org/10.1007/s00703-012-0182-z

MOCKUS, V. National Engineering Handbook: section 4 hydrology. Washington: USDA, 1964.

MONTEITH, J. L. Evaporation and environment. Cambridge: Cambridge University Press, 1965.

MORIASI, D. N.; ARNOLD, J. G.; VAN LIEW, M. W.; BINGNER, R. L.; HARMEL, R. D.; VEITH, T. L. Model Evaluation Guidelines for Systematic Quantification of Accuracy in Watershed Simulations. Transactions of the ASABE, v. 50, n. 3, p. 885-900, 2007. http://dx.doi.org/10.13031/2013.23153

NASH, J. E.; SUTCLIFFE, J. V. River Flow Forecasting Through Conceptual Models Part I-a Discussion of Principles. Journal of Hydrology, v. 10, n. 3, p. 282-290, 1970. https://doi.org/10.1016/0022-1694(70)90255-6 
NEITSCH, S. L.; ARNOLD, J. G.; KINIRY, J. R.; WILlIAMS, J. R. Soil and Water Assessment Tool theoretical documentation. Washington: USDA-ARS, 2005. 494 p.

NEITSCH, S. L.; ARNOLD, J. G.; KINIRY, J. R.; WILlIAMS, J. R. Soil and water assessment tool theoretical documentation version 2009. Texas: Texas Water Resources Institute, 2011.

OLIVEIRA, V. A.; MELLO, C. R.; VIOLA, M. R.; SRINIVASAN, R. Assessment of climate change impacts on streamflow and hydropower potential in the headwater region of the Grande river basin, Southeastern Brazil. International Journal of Climatology, v. 37, n. 15, p. 5005-5023, 2017. https://doi.org/10.1002/joc.5138

OLIVEIRA, V. A.; MELLO, C. R.; VIOLA, M. R.; SRINIVASAN, R. Land-use change impacts on the hydrology of the upper Grande River Basin, Brazil. Cerne, v. 24, n. 4, p. 334-343, 2018. http://dx.doi.org/10.1590/01047760201824042573

PESQUERO, J. F.; CHOU, S. C.; NOBRE, C. A.; MARENGO, J. A. Climate downscaling over South America for 1961-1970 using the Eta Model. Theoretical and Applied Climatology, v. 99, p. 75-93, 2010. https://doi.org/10.1007/s00704-009-0123-z

PINTO, L. C.; MELLO, C. R.; NORTON, L. D.; CURI, N. Land-use influence on the soil hydrology: An approach in upper, Grande River basin, Southeast Brazil. Ciência e Agrotecnologia, 43, 2019. https://doi.org/10.1590/1413-7054201943015619

PRIESTLEY, C. H. B.; TAYLOR, R. J. On the Assessment of Surface Heat Flux and Evaporation Using Large-Scale Parameters. Monthly Weather Review, v. 100, n. 2, p. 81-92, 1972. 0493(1972)100\%3C0081:OTAOSH\%3E2.3.CO;2 https://doi.org/10.1175/1520-

RIBEIRO NETO, A.; PAZ, A. R.; MARENGO, J. A.; CHOU, S. C. Hydrological processes and climate change in hydrographic regions of Brazil. Journal of Water Resource and Protection, v. 8, n. 12, p. 1103-1127, 2016. http://dx.doi.org/10.4236/jwarp.2016.812087

RODRIGUES, J. A. M.; VIOLA, M. R.; ALVARENGA, L. A.; MELLO, C. R.; CHOU, S. C.; OLIVEIRA, V. A. et al. Climate change impacts under representative concentration pathway scenarios on streamflow and droughts of basins in the Brazilian Cerrado biome. International Journal of Climatology, v. 40, n. 5, p. 2511-2526, 2020. https://doi.org/10.1002/joc.6347

TEKLESADIK, A. D.; ALEMAYEHU, T.; VAN GRIENSVEN, A.; KUMAR, R.; LIERSCH, S.; EISNER, S. et al. Inter-model comparison of hydrological impacts of climate change on the Upper Blue Nile basin using ensemble of hydrological models and global climate models. Climatic Change, v. 141, n. 3, p. 517-532, 2017. https://doi.org/10.1007/s10584-017-1913-4

TEUTSCHBEIN, C.; SEIBERT, J. Bias correction of regional climate model simulations for hydrological climate-change impact studies: Review and evaluation of different methods. $\begin{array}{lllllll}\text { Journal of Hydrology, v. 456, p. } & \text { 12-29, }\end{array}$ https://doi.org/10.1016/j.jhydrol.2012.05.052

TODINI, E. The ARNO rainfall-runoff model. Journal of hydrology, v. 175, p. 339-382, 1996. https://doi.org/10.1016/S0022-1694(96)80016-3 
VIOLA, M. R.; MELLO, C. R.; BESKOW, S.; NORTON, L. D. Impacts of Land-use Changes on the Hydrology of the Grande River Basin Headwaters, Southeastern Brazil. Water $\begin{array}{lllllll}\text { Resources Management, } & \text { v. 28, } & \text { n. 13, }\end{array}$ https://doi.org/10.1007/s11269-014-0749-1

WATANABE, M.; SUZUKI, T.; O'ISHI, R.; KOMURO, Y.; WATANABE, S.; EMORI, S. et al. Improved climate simulation by MIROC5: Mean states, variability, and climate sensitivity. Journal of Climate, v. 23, n. 23, p. 6312-6335, 2010. https://doi.org/10.1175/2010JCLI3679.1 